\title{
REJ GÓRNICKIEGO. FILOLOGICZNE ŚLEDZTWO W SPRAWIE SKATOLOGICZNYCH „TREFNOŚCI”
}

Słowa kluczowe: Mikołaj Rej, Łukasz Górnicki, Baldesar Castiglione, facecje, kultura dworska Keywords: Mikołaj Rej, Łukasz Górnicki, Baldesar Castiglione, jests, court culture

\section{O Reju, co nie hołdował pięknej zasadzie Górnickiego}

Druga spośród czterech odsłon „gier rozmownych”, które wypełniają karty Dworzanina polskiego, wskazuje dworzaninowi drogę do rozśmieszania i radowania innych „trefną powieścią” $(29,200)^{1}$. I chociaż poobiednia rozmowa prowadzona „ku obostrzeniu rozumu” (29) dotyka nie tylko sekretów dwornego trefnowania, Księga wtóra dzieła Górnickiego przyciagała uwagę badaczy zwłaszcza ze względu na wykład o wzbudzaniu śmiechu. A ponieważ w księdze tej trzykrotnie pojawia się postać Mikołaja Reja, nie mogli oni nie odnotować i nie skomentować jej przywołania.

Po raz pierwszy napomyka o Reju Aleksander Myszkowski w swoim wywodzie o szczególnej sile dobrego i złego „mnimania” (180-188). Jako przykład władzy wyobrażenia nad człowiekiem przedstawia opowieść o miłosnym liście pięknej a zacnej białogłowy, co to słuchając od innej „słodkich słów o dobrym panie, którego [...] nigdy [...] nie widziała" (184), rozmiłowała się w nim i zapragnęła do niego napisać. Jej list został przejęty i przeczytany przez kolejną nadobną damę, a „lube” i „pełne ognia słowa” (184) okazały się niczym „trucizna”, przygotowana wprawdzie dla „szczurka”, ale zjedzona wpierw przez mysz czy kotkę (185). Przy czym czytelniczka, „,chciwa [...] wiedzieć tajemnice [...] drugich białychgłów" i wskutek tego zapalona miłosnym ogniem, nie była bynajmniej ostatnią ofiarą „mnimania” o „udatnym” młodzieńcu $(185,183)$.

${ }^{1}$ Łukasz Górnicki, Dworzanin polski, ed. Roman Pollak, Biblioteka Narodowa I 109 (Wrocław: Ossolineum, 2004). Wszystkie cytaty z Dworzanina polskiego pochodzą z tej edycji, liczba w nawiasie po przytoczeniu lub przywołaniu tekstu wskazuje stronę. 
Opowiastka ta wywołuje wybuch śmiechu Stanisława Bojanowskiego i uwagę, że gdyby „ten tam pan” był „chłopem nikczemnym”, a nawet „pół psa, pół kozy”, i tak niewiasty walczyłyby o niego, bo „są miedzy sobą zazdrościwe” i „to ich obyczaj przylgnąć do gorszego, a jako owce to czynić, co pirwsza uczyniła” (186).

W obronie kobiet tak prześmiewczo odsądzanych od rozumu stają Andrzej Kostka i sam Myszkowski. Pierwszy zwięźle stwierdza, że taka „powieść” lży nie białogłowy, lecz Bojanowskiego i dlatego - by „za swój występ” odebrał „godną zapłatę" - nie zamierza wyprowadzać go z błędu (186). Drugi zaś przekonuje, że uleganie cudzej opinii często przydarza się także „ludziom mądrym”, i stwierdza, że po wielekroć było udziałem i Bojanowskiego, i innych uczestników prądnickiej rozmowy. Na dowód zaś powiada:

Pomnię ja niedawno, kiedy tu na Prądnik przyniesiono było dwoje wiersze, jakoby miały być jedne pana-Rejowe, a drugie pana Jana Kochanowskiego; wszyscyśmy je z podziwieniem wielkiem chwalili jako trefne, jako smaczne, jako uczone; potym gdy sie to odkryło, iż były czyjeś insze, hnet straciły tę cenę i zdały sie barzo daleko od dobrych [187].

Po raz drugi wzmianka o Reju pojawia się już w tej partii Księgi wtórej, która uczy, ,jako trefności używać” (200). Gdy Jan Derśniak przybliża rozmówcom typ żartów zasadzających się na wypowiedzianym „z prętka” ,jednym telko, krótkim” i „zwięzliwym [...] rzeczeniu”, podkreśla, że z tego rodzaju „trefności [...] ta jest najsubtelniejsza”, która wynika z dwuznacznego „słowa abo rzeczy dwuwykładnej” (228). I za przykład owej najsubtelniejszej odmiany trefnowania podaje wypowiedź Mikołaja Reja:

Jako mając raz dworzanie jeść u pana Mikołaja Tarła, chorążego sędomirskiego, pytał jeden drugiego przed królem stojąc: „Panie, a wszak u Tarła?” - Jaki taki odpowiedział: „U Tarła”; aż do pana Reja przyszło, który, gdy go też spytano: „Panie, a wszak u Tarła?” - on zaraz, by z bicza, ze dwu jedno uczynił słowo i rzekł: „Wie ją djabeł, jać-em jej tam w ogon [= zadek] nie patrzał" [229].

Po raz trzeci wreszcie mowa o Reju pośród żartów ilustrujących godne pochwały użycie porównania (245). Jako drugi przykład „foremnie” zastosowanego podobieństwa Jan Derśniak przytacza słowa Rejowe:

Białegłowy [...] nasze są podobne czaplam, bo jako czapla bez przestanku je a gdziekolwiek leci, to $\mathrm{z}$ niej pierzcha, tak białegłowy nasze ustawicznie jedzą i ustawicznie też chodzą dla chłodu na komórkę [246].

Z tych trzech napomknień o Mikołaju Reju pierwsze zajmowało badaczy w niewielkim stopniu. Przytaczano je zwykle na dowód uznania Górnickiego nie dla autora Figlików, lecz dla twórcy Fraszek. Podkreślano przy tym niekiedy, że opowiastka Myszkowskiego o wierszach, które „przyniesiono” na dwór w Prądniku, dowodzi, że teksty Kochanowskiego czytane były i podziwiane przed 
wydrukowaniem ${ }^{2}$. Jeśli zaś pamiętano, iż $\mathrm{w}$ anegdocie tej obaj pisarze mieli układać wiersze równie „trefne”, „smaczne” i „uczone” (187), to odnotowywano osobliwość takiego osądu w zestawieniu z przekonaniem, że „przewagę artyzmu Kochanowskiego nad artyzmem Reja możemy wyśledzić niemal na każdym kroku" ${ }^{3}$.

Najżywszy oddźwięk w badaniach wywołała wypowiedziana „z prętka” odpowiedź Reja na pytanie o ucztę „u Tarła”. Opatrywano ją mianem „niezbyt wytwornego”, „nieprzyzwoitego” lub wprost „cynicznego” kalamburu ${ }^{4}$, „rubasznego dictum” bądź też „konceptu”, co „subtelnością nie grzeszy” i bardziej pasuje „do winiarni pod Operiaszem aniżeli do przedpokoju królewskiego na Wawelu"s. Przekonanie, że żart Reja jest „błyskotliwym konceptem”, a on sam okazał się „mistrzem w operowaniu paronomazją" ${ }^{\circ}$, pozostaje odosobnione. Badacze skłonni byli bowiem mniemać, że Górnicki, choć „z pewnością mniej jowialny i rubaszny niż Rej, [...] nie zawsze się w tej mierze utrzymał", a opowiadając facecje nacechowane „wytwornym humanistycznym tonem, nie zdołał się jednak [...] ustrzec przed niewybrednymi powiastkami [...] w stylu Rejowych Figlików"

${ }^{2}$ Vide Janusz Pelc, „Przemiany świadomości poetyckiej Jana Kochanowskiego”, in Jan Kochanowski i kultura odrodzenia, ed. Zdzisław Libera et Maciej Żurowski (Warszawa: PWN, 1985), 64; Mirosław Korolko, Jana Kochanowskiego żywot i sprawy: Materiały, komentarze, przypuszczenia (Warszawa: Wiedza Powszechna, 1985), 85.

${ }^{3}$ Jerzy Starnawski, „Rej - Kochanowski”, in idem, Z dziejów renesansu w Polsce: Studia i szkice. Studia Staropolskie. Series Nova 14 [70] (Warszawa: Instytut Badań Literackich PAN, 2007), 109. Cf. Mikołaj Rej - w pięćsetlecie urodzin, vol. 2: Interpretacje, recepcja, ed. Jan Okoń et al. (Łódź: Wydawnictwo Uniwersytetu Łódzkiego, 2005), 350: [Zapis dyskusji, wypowiedź J.Z. Lichańskiego:] „teraz w pełni rozumiem, dlaczego Górnicki z nieprawdopodobną estymą odnosi się do Reja. Zawsze wydawało mi się to dziwne [...]".

${ }^{4}$ Stanisław Dobrzycki, Z dziejów literatury polskiej (Kraków: Spółka Wydawnicza Polska, 1907), 134; Stanisław Windakiewicz, Mikołaj Rej z Nagłowic (Lublin: Arct i Spółka, 1922), 19; Aleksander Brückner, Mikołaj Rej: Studium krytyczne (Kraków: Drukarnia Uniwersytetu Jagiellońskiego, 1905), 39.

${ }^{5}$ Janusz Stanisław Gruchała, „Łukasza Górnickiego teoria trefnowania”, in Łukasz Górnicki i jego czasy, ed. Barbara Noworolska i Wiesław Stec (Białystok: Dział Wydawnictw Filii UW, 1993), 123; Julian Krzyżanowski, „Facecja staropolska”, in Dawna facecja polska, ed. Julian Krzyżanowski et Kazimiera Żukowska-Billip (Warszawa: Państwowy Instytut Wydawniczy, 1960), 12; Julian Krzyżanowski, „O «Figlikach» Mikołaja Reja”, in Mikołaj Rej, Figliki, ed. Maria Bokszczanin (Warszawa: Państwowy Instytut Wydawniczy, 1974), 17 (jak głosi Nagrobek Gąsce z Fraszek Jana Kochanowskiego, „Pod Operyjaszem” „harcował” błazen Gąska, vide Jan Kochanowski, Fraszki, ed. Janusz Pelc, Biblioteka Narodowa I 163 \{Wrocław: Ossolineum, 1991\}, 155 \{III 79, w. 2\}).

${ }^{6}$ Maria Wichowa, „Aspekt ludyczny «Żywota człowieka poczciwego» Mikołaja Reja”, Acta Universitatis Lodziensis. Folia Litteraria Polonica 10 (2008): 4.

${ }^{7}$ Jerzy Ziomek, Renesans (Warszawa: Państwowe Wydawnictwo Naukowe, 1980), 383; Janusz Stanisław Gruchała, „,ukasz Górnicki - «Dworzanin polski»”, in Lektury polonistyczne, vol. 1, ed. Andrzej Borowski, Janusz Stanisław Gruchała (Kraków: Universitas, 1995), 122; cf. Marta Polańska, „Literacka antroponimia jako stylistyczne narzędzie języka”, in Wokót Kochanowskiego i jego czasów: Materiały sesji nuakowej poświęconej kulturze literackiej Matopolski $w$ dobie renesansu. Kielce, 10-11 października 1992, ed. Maria Garbaczowa (Kielce: Wyższa Szkoła Pedagogiczna im. 
Wreszcie zaś porównanie białogłów z czaplami, jakkolwiek komentowane z rzadka, także uznano za „niesmaczne” i „bardzo niepochlebne, dowodzące, jak” Rej „mało cenił niewiasty”. Łączono je przeto z jego nieprzychylnym wobec kobiet dialogiem „Warwasa z Dykasem”, sugerując nawet, że jest ono cytatem $\mathrm{z}$ tego - nie znanego dziś w całości - utworu? .

U początku Pirwszej księgi swego dzieła Łukasz Górnicki obszernie wykłada, co i dlaczego przekształcił z pierwowzoru, by z włoskiego Il Cortegiano „polskiego Dworzanina uczynił” (8). Objaśnia między innymi, iż rozmowę prowadzą u niego osoby historyczne - dworzanie, którzy wprawdzie w tym samym czasie „u dworu ze sobą nie byli”, ale „znali sie z sobą po społu” (20). Jak zresztą wynika ze wstępu do Księgi czwartej, gdy czynił ich postaciami swego utworu, wszyscy już nie żyli (401-404). Żył natomiast i znajdował się u szczytu sławy Mikołaj Rej, a 36-letni Jan Kochanowski zdobywał coraz większy rozgłos. Tłumacząc swoiste zastosowanie zasady prawdopodobieństwa, Górnicki zaznacza, że „Kochanowskiego [...] wirsze pod ten czas, gdy go ja wspominam, jeszcze się były nie wsławiły; ale to nic, bo jednak rychło potym pan Kochanowski wirsz pisać począł" (20). Objaśnienie to wprost odnosi się do pierwszej z trzech wzmianek o Reju, bo przecież mowa w niej o pochwałach, jakimi obsypać miano teksty ułożone rzekomo przez niego oraz przez Kochanowskiego.

A jednak dwie pozostałe wzmianki, wplecione w wywód o trefnowaniu, badacze uznali - nie bacząc na zastrzeżenia Górnickiego - za wierne poświadczenie rzeczywistego wydarzenia na dworze królewskim oraz za wierne przytoczenie „podobieństwa” wypowiedzianego bądź napisanego przez Reja ${ }^{10}$. W przekonaniu tym mógł utwierdzać ich rys skatologiczny obu żartów, spokrewniający je $\mathrm{z}$ bogatą grupą ponad pięćdziesięciu Rejowych figlików ${ }^{11}$.

Skoro zaś pisarz niemal czwartą część swego zbioru facecji poświęcił „przypadkom ludzkim"12 łączącym się mniej lub bardziej bezpośrednio z wydalaniem, stwierdzano, iż „nie hołdował” on „pięknej zasadzie Górnickiego”, który

Jana Kochanowskiego, 1994), 226-227; Radosław Grześkowiak, Edmund Kizik, „Wstęp”, in Sowiźrzat krotochwilny i śmieszny: Krytyczna edycja staropolskiego przekładu „Ulenspiegla”, ed. Radosław Grześkowiak, Edmund Kizik (Gdańsk: Wydawnictwo Uniwersytetu Gdańskiego, 2005), VII, XXXI-XXXIII; Witold Wojtowicz, Między literatura a kulturą: Studia o „literaturze mieszczańskiej” przetomu XVI i XVII wieku (Szczecin: Wydawnictwo Naukowe Uniwersytetu Szczecińskiego, 2010), 272.

${ }^{8}$ S. Windakiewicz, op. cit., 19; A. Brückner, op. cit., 42.

${ }^{9}$ A. Brückner, op. cit., 42; J. Starnawski, op. cit., 27-28.

${ }^{10}$ Obok przywołanych już opracowań vide Bogdan Walczak, „Staropolski dowcip onimiczny”, Prace Filologiczne 37 (1992): 282. Co znamienne, w wypadku wypowiedzi Anny Kochanowskiej Dobrzycki zachowuje ostrożność, pisząc, że matce Jana Kochanowskiego „Górnicki kładzie w usta żart rzeczywiście doskonały, choć na dzisiejsze pojęcia mocno nieprzyzwoity” (S. Dobrzycki, op. cit., 133-134).

${ }^{11}$ Vide Paweł Stępień, Śmiech w czasach ostatecznych: Tematyka religijna w „Figlikach” Mikołaja Reja (Warszawa: nakładem Wydziału „Artes Liberales” UW, 2013), 54.

${ }^{12}$ M. Rej, op. cit., 41 (Ku temuż, co czyść będzie). 
dlatego pominął kilkanaście anegdot włoskiego pierwowzoru, że „mogłyby [...] «poczciwe uszy obrazić»"13. Postrzegano Reja jako autora, co to „nie cofa się przed opowiadaniem brudnych i często wstrętnych" dykteryjek, ma słabość do „przypowieści wulgarnych, prostackich” oraz utrwala w Figlikach „wybryki sprośnej i rubasznej fantazji sarmackiej”"14. „Zanosi się” przy tym „głośnym, rubasznym śmiechem”, nie baczy na „dyskrecję, finezję, przyzwoitość” i hołduje zasadzie „naturalia non sunt turpia” ${ }^{15}$.

Przejawu szczególnego upodobania do tematyki skatologicznej Ignacy Chrzanowski upatrywał w dążności polskiego pisarza do takiego przekształcania pierwowzoru figlika, by w miejsce innego rodzaju humoru wprowadzić humor związany $\mathrm{z}$ trawieniem i defekacją. Oto więc

W facecji Abstemiusa De muliere, amatoris discessum flente kobieta płacze po śmierci kochanka, a gdy pyta, czemu tak płacze, odpowiada: „non discessum eius, sed pallium, quod ei reliqui, fleo”; u Reja zaś „chłopa żona zdechłego gdy we wsi chowała”, narzeka głównie na to, że w nocy nie będzie już miała powodu do śmiechu z gróźb i próśb męża, aby zachowywała się spokojnie. Facecja ta bardzo dosadnie charakteryzuje rubaszny humor Reja $[\ldots]^{16}$.

Ów „rubaszny humor Reja” był w 1894 roku tak rażący, że nawet w przeznaczonych dla nielicznych a uczonych czytelników „Rozprawach Akademii Umiejętności” Wydziału Filologicznego „trudno” było Chrzanowskiemu „przytoczyć [...] w całości" omawiany figlik ${ }^{17}$. Tymczasem bez zacytowania utworu niełatwo odgadnąć, co kryje się pod przyzwoitą formułą o śmiechu żony „z gróźb i próśb męża, aby zachowywała się spokojnie":

\section{Jako żona męża żałowała}

Chłopa żona zdechłego gdy we wsi chowała,

Miedzy inym nieszczęściem na to narzekała.

- «Ach, mój miły Marcinie! Już mój śmiech ustanie,

Kiedyś ono więc przez sen czasem wołał na mię:

- „O, miła Machno, nie bzdzi!” - Tom sie ja uśmiała!

A któż mi to dziś rzecze, bych sie i usrała.

Albo gdyś mi więc groził: - „Ba, wieręć dam piętą,

Jesliże sie nie stulisz, w tę dupę przeklętą!"” ${ }^{18}$.

${ }^{13}$ Ignacy Chrzanowski, „Facecje Mikołaja Reja”, Rozprawy Akademii Umiejętności. Wydziat Filologiczny 23 (ser. 2, vol. 8) (1894): 332.

${ }^{14}$ Ibidem, 321; J. Krzyżanowski, „O «Figlikach»”, 17; A. Brückner, op. cit., 263.

${ }^{15}$ A. Brückner, op. cit., 253.

${ }^{16}$ I. Chrzanowski, op. cit., 358. Sugestię, że facecja Abstemiusa jest pierwowzorem figlika Jako żona męża żałowała, podtrzymał Chrzanowski w edycji: Biernat z Lublina, Ezop, ed. Ignacy Chrzanowski (Kraków: nakładem Akademii Umiejętności, 1910), 245, przypisy źródłowe do bajki 141. Miłośnice sa drapieżnice. Za Chrzanowskim oba teksty - Abstemiusa i Biernata - wskazała jako źródło utworu Reja Maria Bokszczanin, vide M. Rej, op. cit., 188, przypis do figlika 71. Jako żona męża żałowała.

${ }^{17}$ Ibidem.

${ }^{18}$ M. Rej, op. cit., 76 (figlik 71.). 
Sugestii, że utwór ten stanowi parafrazę bajki Abstemiusa De muliere amatoris discessum flente, nie da się utrzymać. Nie mówi ona bowiem o śmierci, lecz o odjeździe kochanka, ogołoconego przez nierządnicę z niemal wszystkich dóbr. Ponadto o ile Rej ukazuje nazbyt szczery lament chłopskiej małżonki, wprost ujawniającej jedną z przyczyn swego bólu, o tyle Abstemius przedstawia niepocieszony płacz „bezwstydnej niewiasty”, który na pozór dowodzi jej miłości do odchodzącego mężczyzny. Na pozór, albowiem zapytana przez sąsiadkę wyznaje, że przyczyną żalu jest płaszcz - jedna z nielicznych rzeczy, jakich dotąd nie odebrała kochankowi:

De muliere amatoris discessum flente

Mulier impudica amatorem suum abeuntem, quem omnibus fere rebus spoliauerat, multis lachrymis prosequebatur. Interrogante autem eam uicina, cur ita inconsolabiliter fleret, „Non discessum eius”, inquit, „sed pallium, quod ei reliqui, fleo”.

Fabula indicat non amatores, sed eorum bona a meretricibus amari ${ }^{19}$.

Choć jednak figlik Jako żona męża żałowała nie powstał raczej wskutek przeobrażenia bajki De muliere amatoris discessum flente, nie musi to oznaczać, że w zbiorze Reja nie ma parafrazy nasycającej pierwowzór tematyką skatologiczną.

Jesienią 1562 roku gotowe było już do druku w oficynie Oporina dzieło Johannesa Manliusa Locorum communium collectanea [...] pleraque tum ex lectionibus domini Philippi Melanchthonis, tum ex aliorum doctissimorum uirorum relationibus excerpta $[\ldots]^{20}$. Pośród rozmaitych przykładów, podobieństw,

${ }^{19}$ Laurentius Abstemius, Fabul[a]e per latinissimum uirum Laurentium Abstemium nuper composite [Aesopus], Fabulae ex graeco in latinum per Laurentium Vallam, uirum clarissimum, uersae (Venetiis: Ioannes de Cereto, 1499), k. a6r, fabula XV. Cf. Biernat z Lublina, Miłośnice są drapieżnice: Niegdy jedna miłośnica, / Złupiwszy swego panica, / Żałowała, gdy od niej jał, / Smutnymi ją słowy żegnał. // A gdy ciężko narzekała, / Jakoby syna pogrzebała, / Towarzyszki, co z nią były, / Jako mogąc, ją cieszyły, // Rzekąc: „Nie płacz bez przyczyny! / Na to mieśce przydzieć inny”. / Ona więc płakać przestała, / Tako im odpowiedziała: // „Ni przetomci tak płakała, / Iżebych go żałowała: / Jednoć mi tego barzo żal, / Iż mi tego płaszcza nie dał". // Łzam sie nie trzeba dziwować / Ani na płacz wielki patrzać: / Mnodzyć ten obyczaj mają, / Łzami zdrady przykrywają” (Biernat z Lublina, op. cit., 245, bajka 141). Chrzanowski podtrzymuje tu swe rozpoznanie, w pełni świadom, że streszczenie „w facecji Abstemiusa De muliere, amatoris discessum flente kobieta płacze po śmierci kochanka” jest błędne, a porównanie z figlikiem Reja opiera się na założeniu, że w obu utworach występuje kobieta opłakująca zmarłego.

${ }^{20}$ Iohannes Manlius, Locorum communium collectanea [...] pleraque tum ex lectionibus domini Philippi Melanchthonis, tum ex aliorum doctissimorum uirorum relationibus excerpta [...], in quibus varia [...] exempla, similitudines, sententiae, consilia, bellici apparatus, stratagemata, historiae, apologi, allegoriae, sales [...] continentur (Basileae: per Ioannem Oporinum, 1563). List polecający Simona Sulzera, „Academiae Basiliensis rectoris”, datowany jest: „Basileae, pridie Cal[endas] Octobr[is] Anno Domini 1562”, czyli 30 września 1562 (ibidem, k. B3r), elegia In librum Ioannis Manlii, ad lectorem datowana jest „MDLXII, mense Octobri” (ibidem, k. ß4r), pieśń zaś Manliusa: „Basileae, Anno Christi 1562, mense Nouembri” (ibidem, 284). 
sentencji, bajek, alegorii, żartów, z których część miała być zapisem słów zmarłego w 1560 roku Filipa Melanchtona, twórca zbioru umieścił exemplum o karze za lekceważenie zbawczego dzieła Syna Bożego:

\begin{abstract}
Cum ageretur in quodam celebri loco tragoedia de passione et morte Domini nostri Iesu Christi, quidam agens personam pendentis in cruce Saluatoris nostri, accepto in corde lethali uulnere, ab alio petente uesicam cruore impletam, et lateri ipsius alligatam, mortuus concidit; alium etiam, qui deflentis sub cruce personam repr[a]esentabat, lapsu interemit, cuius mortem frater uindicans in eo, qui ipsum in ligno pendentem sauciauit, capitali supplicio affectus est. Ita quatuor occubuerunt non sine suspicione, quod homines in tam seriis rebus ludant; praesertim cum id fieri non possit sine offensione piorum hominum ac Deum timentium. Est etiam poena, qua Deus iram suam uult ostendere aduersus contemptores passionis Domini nostri Iesu Christi, quam amplius repraesentari non uelit ${ }^{21}$.
\end{abstract}

Niemal pół wieku później, w roku 1611, powiastkę tę, godzącą w katolicką tradycję misteriów pasyjnych, przytoczy w swej Postylli kalwiński kaznodzieja, Krzysztof Kraiński. W Kazaniu na Wielki Piatek, w Przedmowie do czytania Pasyjej, piętnuje on „sprosne zabobony i szkarade bałwochwalstwa” Kościoła rzymskiego, wspominając m.in. o widowiskach przedstawiających przebieg Męki ${ }^{22}$. Podążając śladami szwajcarskiego teologa, Rudolfa Hospiniana, kaznodzieja przywołuje opinię Juana Luisa Vivesa o spektaklach pasyjnych, po czym parafrazuje exemplum Manliusa $^{23}$. Skoro zaś, według Vivesa, misteria „nie mogą być [...] bez wielkiego śmiechu i chechotania patrzących" ${ }^{24}$, Kraiński opatruje je mianem komedii:

$\mathrm{K}$ temu dzisia plebanowie w miasteczkach komedyje stroją, zmyślając osobę Chrystusowę, apostolską, Judaszowską, żydowską i inszych. [...] Te jednak komedyje źle się im nadawają i nadawały. Pisze bowiem Manlius, jako w jednym mieście, kiedy takową komedyją sprawowano, tedy ten, ktory na sobie niosł osobę [= odgrywał rolę] onego żołnierza, ktory włocznią przekłoł bok Pański, chcąc rzekomo przebić bok onemu, ktory na sobie niosł osobę wiszącego Chrystusa, miasto męcherzyny [= pęcherza], ktorą mu było u boku uwieszono nalawszy krwie, trafił go w bok i tak umarł. Ktory, lecąc z krzyża, tego, ktory pod krzyżem stał, niosąc na sobie osobę płaczącego, zabił sobą. Ktorego się brat mszcząc zabił owego, ktory miasto męcherzyny w serce wiszącego trafił. Ktorego potym oń ścięto. I tak czterzej polegli za przyczyną onej komedyjej. A to się zstało nie bez dziwnego sądu Bożego. Nie chce bowiem Pan Bog, abyśmy

${ }^{21}$ Ibidem, 11 (w dziale Poena contemptus officiorum filii Dei, vide ibidem, 10). O znaczeniu terminu officium Christi m.in. u Melanchtona vide Georg Christian Knapp, Vorlesungen über die christliche Glaubenslehre nach dem Lehrbegriff der evangelischen Kirche, vol. 2 (Halle: in der Buchhandlung des Waisenhauses, 1827), 222-223 (§ 105 I).

${ }^{22}$ Krzysztof Kraiński, Postylla Kościoła powszechnego apostolskiego [...] (Łaszczów: Sebastian Sternacki, 1611), k. 190r.

${ }^{23}$ Vide Rodolphus Hospinianus, Festa Christianorum, hoc est De origine, progressu, ceremoniis et ritibus festorum dierum Christianorum [...] (Tiguri: apud Ioannem Wolphium, 1593), k. 65v (rozdział De Septimana in Albis w części De origine festorum christianorum). Tu precyzyjnie oznaczone przywołanie zarówno uwag Vivesa, jak i exemplum Manliusa.

${ }^{24}$ K. Kraiński, op. cit., k. 190r. 
figlami, łątkami [= lalkami teatralnymi], igrzyskami i śmieszkami śmierć okrutną Syna jego miłego przypominali i nimi onę konterfetowali [= przedstawiali $]^{25}$.

Niewykluczone, że ewangelickie exemplum o nieszczęśliwym odegraniu sceny przebicia boku było szerzej znane, zanim Manlius utrwalił je w swoim zbiorze. I być może to właśnie ono stanowiło tekst, który Rej przekształcił w wiersz Co na krzyżu chtopy posrat:

Mniszy gdy w Wielki Piątek igrę sprawowali,

Chłopa wzgórę nagiego na krzyż wszrotowali.

U boku macharzynę ze krwią powiesili,

Drugiego, by ją przekłuł ślepo, przyprawili.

Błazen wtenczas przybieży na kęsym koniku,

Porwie włócznią: - «Postój ty, ślepy pacholiku!»

Bieży z włócznią do boku, chłop na krzyżu spierdzi

I posrał apostoły. - «Szpetnie nasz pan śmierdzi.» ${ }^{26}$.

W zwięzłej, ośmiowersowej ramie figlika niełatwo byłoby zmieścić złożoną opowieść o łańcuchu czterech zgonów, w której niefortunna próba przebicia pęcherza napełnionego krwią skutkuje śmiercią dwu aktorów, brat zaś jednego $\mathrm{z}$ nich zabija mimowolnego sprawcę wypadku i płaci głową za zemstę. Wydaje się przeto prawdopodobne, że poeta, nie odbiegający w pierwszych czterech wersach od historii opublikowanej przez Manliusa, zadecydował o jej przeobrażeniu. W czterech kolejnych wersach utworu pojawia się zatem postać błazna, który - chwyciwszy ostrą włócznię - pędzi na kucyku, by przebić „macharzynę ze krwią", ukazana jest szczególna reakcja zatrwożonego odtwórcy roli Chrystusa oraz przytoczony komentarz zapewne jednego z widzów przedstawienia. Nie wiadomo, czy błazeńska interwencja w przebieg misterium kończy się zaledwie fizjologicznym paroksyzmem aktora, czy też prowadzi do jego zranienia bądź śmierci. Z pewnością jednak Rej rozstrzygnął, że uderzy w katolicką tradycję misteriów pasyjnych poprzez skupienie się nie na krwawych następstwach dążności do realistycznego odegrania Męki, lecz na skatologii.

Wszelako - jeśli nawet przypuszczenie o źródle misteryjnej facecji jest trafne - gotowość polskiego pisarza do podejmowania tematyki wiążącej się z wydalaniem nie rozjaśnia przyczyn włączenia dwu wzmianek o żartach Reja do wywodu o dwornym trefnowaniu. Zrozumienia decyzji Górnickiego nie ułatwia też ani hipoteza, że wywód ten powstał w odpowiedzi na zawarte w Figlikach „dowcipy prostackie” i „cuchnące ekskrementami”27, ani wspomniane już założenie,

${ }^{25}$ Ibidem, k. 190r-190v.

${ }^{26}$ M. Rej, op. cit., 135 (figlik 189.). O odniesieniu przytoczonego utworu Reja do tradycji facecjonistycznej vide I. Chrzanowski, „Facecje”, op. cit., 343; P. Stępień, op. cit., 132-135.

${ }^{27}$ J. Krzyżanowski, „O «Figlikach»”, 17-18; cf. Sante Graciotti, „Polska facecja humanistyczna i jej włoskie wzorce”, in idem, Od Renesansu do Oświecenia, trans. Wojciech Jekiel et al., vol. 1 (Warszawa: Państwowy Instytut Wydawniczy, 1991), 200. 
że autor Dworzanina nie do końca potrafił sprostać wymogom humanistycznej wytworności ${ }^{28}$.

Żadne bowiem z trzech napomknień o Reju nie zawiera śladów wskazujących na dystansowanie się do jego twórczości czy poczucia humoru. W wywodach o tym, co dworne, nie została mu też przydzielona rola zbliżona do roli Stanisława Bojanowskiego czy Lupy Podlodowskiego, z których pierwszy „nie był w naukach biegły", choć wymowny i obdarzony przenikliwym rozumem (403), drugi zaś żywił niechęć tak do włoskich obyczajów (29), jak do uczoności, zastępującej cnotę mędrkowaniem i wielomówstwem (104).

W pierwszej wzmiance Aleksander Myszkowski przywołuje wspólne wszystkim zebranym wysokie mniemanie o twórczości Reja, tak mocno ugruntowane, że wiersze przedstawione jako „pana-Rejowe” uznali oni za „trefne”, „smaczne” i „uczone” (187). Przy czym ten sam dworzanin podał nieco wcześniej inny przykład przemożnego wpływu opinii: jeśli pan przejawia łaskawość nawet wobec nikczemnika, to „Już takiego wszytek dwór czcić i ważyć będzie, a chocia leda co powie chłopską a grubą trefnością, jako kijem w błoto, przedsię mu sie wszyscy śmieją" (181). W drugiej wzmiance o Reju Górnicki nie łączy bynajmniej skatologicznego żartu o uczcie „u Tarła” z „chłopską a grubą trefnością”. Nie jest to „głupie rzeczenie, któremu sie więc ludzie rychlej niż foremnej powieści śmieją" (202-203). Przeciwnie, Jan Derśniak - biegły w rozśmieszaniu „z nauki” (203) i wtajemniczający słuchaczy w sekrety tej wiedzy - uznaje ową rzuconą „z prętka” wypowiedź za przykład „najsubtelniejszej” trefności (228). $\mathrm{W}$ trzeciej wzmiance zaś porównanie niewiast z czaplami, które „bez przestanku" jedzą i wydalają (246), występuje jako jedno ze świadectw umiejętności, zalecanej przez Derśniaka słowami: „Chwalę też i owo, kiedy kto podobieństwo jakie abo przyrównanie wyrwie i foremnie je przystosuje" (245).

Wprowadzając trzykrotnie Reja na karty Dworzanina polskiego, Górnicki po trzykroć odbiega od tekstu włoskiego. Nie oznacza to wszakże, iż żarty powiązane tu z autorem Figlików muszą być wiernym zapisem jego rzeczywistych wypowiedzi. Nie dowodzi tego również poświadczony w nich typ humoru, choć zbieżny jest $\mathrm{z}$ humorem znanym zwłaszcza $\mathrm{z}$ Rejowych facecji. Zastrzeżenia Górnickiego wyłożone we wprowadzeniu do Pirwszej księgi nie zachęcają bowiem do przyjmowania za pewnik prawdziwości zdarzeń i słów postaci. Zgodnie z jego objaśnieniami istotną rolę odgrywa prawdopodobieństwo i dostosowanie tego, co zmienił w stosunku do pierwowzoru, oraz tego, co dodał (21), do celów, jakie sobie postawił podejmując się „napisania po polsku Dworzanina” (19).

Dociekanie więc, na ile prawdziwe są oba - bez wątpienia prawdopodobne - „rzeczenia” Reja, nie przybliża do odpowiedzi na pytanie o powody ich umieszczenia w wykładzie o „foremnym” trefnowaniu (211). Wnikliwa analiza

\footnotetext{
${ }^{28}$ Vide przyp. 7.
} 
Figlików, uwzględniająca ich źródła, odniesienie do tradycji gatunku facecji oraz kontekst innych dzieł pisarza, pomocna jest w tej mierze, iż podważa zasadność jego wizerunku jako owładniętego przez żywioł bądź to prostackiej, bądź to sarmackiej rubaszności i pozwala dostrzec twórcę, który w pełni świadomie, z rozwagą i konsekwencją wykorzystuje reguły gatunkowe i skatologiczny wymiar facecjonistyki do realizacji najpoważniejszych zadań ${ }^{29}$. Poza tym jednak wyniki tej analizy nie będą przydatne. Jakkolwiek bowiem Górnicki wysoko ocenia twórczość Reja, to przypisane mu próbki trefności z pewnością dostosowuje do swoich, nie Rejowych celów. Wypada więc skupić się uważniej na obu żartach przywołanych w wywodzie Derśniaka, sprawdzając, jak wypełniają one zarysowane przez niego wymogi dwornego rozbudzania śmiechu, sięgając - gdy okaże się to użyteczne - do źródeł Dworzanina polskiego oraz posiłkując się kontekstami, zwłaszcza facecjonistyki oraz staropolskich utworów satyrycznych.

\section{Białogłowy i czaple, czyli foremnie przystosowane podobieństwo}

Gdy w drugiej księdze włoskiego Dworzanina messer Bernardo podejmuje temat wywoływania śmiechu poprzez użycie porównań, zaznacza, że niektórzy znajdują przyjemność w porównywaniu mężczyzn i kobiet nie tylko do koni, psów bądź ptaków, ale też do skrzyń, stołków, wozów lub świeczników. O tym zaś, czy takie zestawienia nacechowane będą wdziękiem, czy pozbawione polotu, rozstrzyga uwzględnienie czasu, miejsca, osób i innych okoliczności istotnych dla sztuki dwornego żartowania ${ }^{30}$.

Górnicki natomiast otwiera poświęconą porównaniu partię wykładu Derśniaka zwięzłą pochwałą nagłego przywołania, „wyrwania” „podobieństwa” i użycia go w taki sposób, by okazało się „przystosowane” „foremnie” (245), czyli zarazem trafnie, zręcznie, misternie i dowcipnie ${ }^{31}$. Polski pisarz pomija przytoczone przez Casiglione’a przykłady: Serafina porównanego do torby podróżnej oraz małoletniego Alessandra Gonzagi przyrównanego do Aleksandra Macedońskiego w wieku chłopięcym. Opuszcza też wymianę zdań dotyczącą unikania bezbożności w dwornym trefnowaniu i wynikły z niej spór o to, czy niewiasty czerpią przyjemność ze słuchania i mówienia o sprawach przyprawiających o rumieniec wstydu ${ }^{32}$. W to miejsce pojawiają się dwa „podobieństwa” zaczerpnięte

${ }^{29} \mathrm{O}$ funkcjach skatologii w figlikach Reja vide P. Stępień, op. cit., 68-72, 88-92, 120-128, $132-135$.

${ }^{30}$ Baldesar Castiglione, Il libro del Cortegiano, a cura di Giulio Preti (Torino: Einaudi), edycja elektroniczna La biblioteca digitale della letteratura italiana, http://www.letteraturaitaliana.net/pdf/ Volume_4/t84.pdf (acc. 31.10.2016), 175-176 (II 67).

${ }^{31}$ Vide Stownik polszczyzny XVI wieku, vol. 7 (Wrocław: Ossolineum, 1973), 95 (s.v. foremnie).

${ }^{32}$ B. Castiglione, op. cit., 175-178 (II 67-69). 
z Cyceronowego De oratore, przeniesione w realia XVI-wiecznej Rzeczypospolitej ${ }^{33}$, a pomiędzy nimi Rejowe porównanie kobiet do ptaków:

Białegłowy [...] nasze są podobne czaplam, bo jako czapla bez przestanku je a gdziekolwiek leci, to $\mathrm{z}$ niej pierzcha, tak białegłowy nasze ustawicznie jedzą i ustawicznie też chodzą dla chłodu na komórkę [246].

Już wcześniej, w rozważaniach o oddziaływaniu dobrej i złej sławy, wiodących ku pierwszej wzmiance o Reju, nazbyt ciekawa niewiasta o sercu rozpalonym przez ogień cudzego miłosnego listu porównana została do myszy bądź kotki, które padają ofiarą trucizny przygotowanej „na szczurka” (185). Niechętny białogłowom i daleki od współczującej postawy Stanisław Bojanowski zestawia je wówczas z owcami, skłonnymi bezrozumnie „to czynić, co pirwsza uczyniła” (186). „Podobieństwo” Rejowe zaś nie wyraża ani współczucia dla kobiecych słabości, ani pogardliwego osądu kobiecej natury.

W XVI stuleciu czapla była ptakiem dobrze znanym miłośnikom polowań i wystawnych strojów. Łowienie jej z użyciem sokołów stanowiło przez wieki rozrywkę cenioną przez władców. A choć czaplę, zawsze chudą, brodzącą na długich nogach w nieustannym poszukiwaniu ryb, żab, raków, postrzegano jako słabe i najtrwożliwsze ze stworzeń ${ }^{34}$, obawiano się, że swym długim dziobem potrafi ona zranić lub wprost uśmiercić spadającego na nią sokoła ${ }^{35}$. Stąd prze-

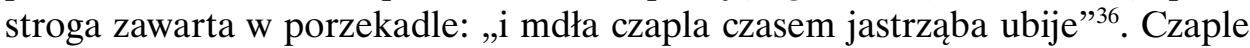
mięso nie uchodziło za przysmak, natomiast zawrotne ceny osiągały kitki z czaplich piór ${ }^{37}$, którymi zdobiono nakrycia głowy ${ }^{38}$. Dlatego też ptaki te chwytano i żywcem. Poświadcza to nie tylko XVII-wieczna przygoda czapli złowionej przez Władysława IV, zaobrączkowanej i uwolnionej, a po 30 latach schwytanej ponownie $^{39}$, ale także przysłowie: „Umizga [= przymila] sie by czapla w kobieli $[=\mathrm{w}$ koszu $] " 40$.

${ }^{33}$ Vide Ł. Górnicki, op. cit., 245, przyp. 827, oraz 246, przyp. 831.

${ }^{34}$ Vide „Historia łowiectwa przed wynalezieniem prochu strzelbowego”, Sylwan: Dziennik Nauk Leśnych $i$ Łowieckich 7 (1830): 340.

${ }^{35}$ Vide Ignacy Bobiatyński, Nauka łowiectwa, vol. 2 (Wilno: drukiem Józefa Zawadzkiego, 1825), 342-343.

${ }^{36}$ Stownik polszczyzny XVI wieku, vol. 4 (Wrocław: Ossolineum, 1973), 5-6 (s.v. czapla).

${ }^{37}$ Vide Szymon Starowolski, Reformacja obyczajów polskich [...], ed. Kazimierz Józef Turowski (Kraków: nakładem Wydawnictwa Biblioteki Polskiej, 1859), 44 (rozdz. 9.).

${ }^{38}$ Vide Łukasz Gołębiowski, Ubiory w Polszcze od najdawniejszych czasów aż do chwil obecnych (Warszawa: drukiem A. Gałęzowskiego i komp., 1830), 169.

${ }^{39}$ Vide Lukasz Gołębiowski, Gry i zabawy różnych stanów w kraju całym lub niektórych tylko prowincjach (Warszawa: druk N. Glücksberga, 1831), 134.

${ }^{40}$ Vide Salomon Rysiński, Przypowieści polskie (Kraków 1619), k. h3r (rozdz. 16); Samuel Bogumił Linde, Stownik języka polskiego, vol. 1 (Warszawa: drukarnia księży pijarów, 1807), 343 (s.v. czapla). Cf. Samuel Bogumił Linde, Stownik języka polskiego, vol. 2 (Warszawa: u autora, 1809), 101 (s.v. miłosierny). 
Już po opublikowaniu Dworzanina polskiego obraz długonogiej postury ustawicznie strwożonego ptaka i jego przymilnego spojrzenia wykorzysta Mikołaj Rej, gdy w Żywocie człowieka poczciwego nakreśli wizerunek tchórzliwego młodzieńca:

Bo wnet tępego a bojaźliwego uźrzysz, gdy co chce poważnego mówić, aliści on piętą wierci, palce skubie, brodę muszcze, postawki [= miny] stroi, rzkomo szepluni, umizga się jako czapla w kobieli, a każde słówko na troje przekąsi ${ }^{41}$.

W poezji XVII stulecia umizgi uwięzionej czapli, bez nawiązania do jej lękliwej natury, pojawiają się w satyrycznym ujęciu zalotnych zachowań naśladujących obyczaje dworu. W Zwroceniu Matyjasza z Podola wytworne starania o pannę wymagają od kawalera, by wygolił się „chędogo”, przypasał szablę, wystawił „beczkę miodu” oraz opłacił muzyków grających do tańca na serbach i cymbałach ${ }^{42}$. Winien on również

[...] co raz to swej pannie bić niziuchno czołem,

Dudkować, umizgać się jak czapla w kobieli.

Tak przy dworze działają, jeśliście widzieli ${ }^{43}$.

Jednakże to nie kawalerowie mieliby przodować w dziele kokieteryjnego przykuwania uwagi. W Sejmie piekielnym przekonuje o tym diabeł Paskuda, sprawujący pieczę nad zalotami. To przecież białogłowa, co „się wymagluje, wymuszcze, wygładzi”, w tym celu „wargi sznuruje, umiezga, pogląda po oku” tudzież śmieje się „co słóweczko”, by roznamiętnić mężczyznę ${ }^{44}$. Wiersz o fortelach i obyczajach białogłowskich ukazuje więc strojną w kryzę młodziutką mieszczkę, która nawet w kościele „umiezga się by czapla”, a „oczyma by sowa strzyże” i „wije” „się” ,jako wąż, głową potrząsając" "45.

Można przeto przypuszczać, że gdy w porównaniu przypisanym Rejowi padały słowa „Białegłowy [...] nasze są podobne czaplam”, słuchacze spodziewali się ciągu dalszego zgodnego z logiką przytoczonych właśnie zestawień: oto jeśli niewiasty wdzięczą się nazbyt usilnie, przypominają przymilającą się czaplę „w kobieli”. W swym wykładzie o dwornym trefnowaniu Górnicki wspiera się

${ }^{41}$ Mikołaj Rej, Żywot człowieka poczciwego, ed. Julian Krzyżanowski, Biblioteka Narodowa I 152 (Wrocław: Ossolineum, 2003), 79-80. Vide Helena Markowska, „Nie tylko gęsi - bestiarium Mikołaja Reja: Symbolika i funkcja zwierząt w «Żywocie człowieka poczciwego»”, Mishellanea 10 (14) (2011): 43-55.

${ }^{42}$ Zwrócenie Matyjasza z Podola: Dialog z pierwszej ćwierci XVII wieku, ed. Teodor Wierzbowski (Warszawa: druk K. Kowalewskiego, 1897), 20-21 (w. 509-511).

${ }^{43}$ Ibidem, 21 (w. 512-514).

${ }^{44}$ Sejm piekielny: Satyra obyczajowa (1622 r.), ed. Aleksander Brückner (Kraków: nakładem Akademii Umiejętności, 1903), 62 (w. 1321,1323, 1325-1326).

${ }^{45}$ Polska satyra mieszczańska: Nowiny sowiźrzalskie, ed. Karol Badecki (Kraków: nakładem Polskiej Akademii Umiejętności, 1950), 155 (w. 109-113). 
wszakże nie tylko na Dworzaninie Castiglione'a, ale również - mocniej nawet niż włoski autor - na traktacie Cycerona $O$ mówcy. Podkreśla zatem, że „najpospolitsza trefność ta jest, kiedy człowiek na swe słowa daleko rozną powieść słyszy, niż ta, której czekał" (230). I podąża tym samym za Cyceronowym twierdzeniem, iż „najbardziej znanym rodzajem żartu jest ten, gdy mówi się coś innego niż to, czego się spodziewamy” ${ }^{46}$. „Śmiech wywołuje bowiem” - uczył rzymski pisarz - „powiedzenie czegoś wbrew oczekiwaniom słuchaczy” 47 .

Lektura dzieła De animalibus Alberta Wielkiego przekonywała, że nie tylko ostry dziób czapli pozwalał jej bronić się przed atakiem drapieżnych ptaków. Inną metodą obrony miało być obryzgiwanie prześladowcy odchodami. Z palącymi wydalinami niektórzy uczeni, co odnotowuje Albert, wiązali nawet łacińskie miano czapli. On sam zaś napomyka o jej nienasyconej żarłoczności łączącej się $\mathrm{z}$ wydalaniem niestrawionego pokarmu ${ }^{48}$.

Wbrew prawdopodobnym oczekiwaniom słuchaczy Rejowe porównanie odwołuje się nie do czaplich umizgów, lecz do tych właśnie - także powszechnie wówczas znanych - cech ptaka: „czapla bez przestanku je a gdziekolwiek leci, to z niej pierzcha". Tym więc, co łączy niewiasty i czaple, okazuje się nieustanne spożywanie. Trudno wszakże założyć, że owo „foremnie” „przystosowane” podobieństwo uderza w jakieś monstrualne obżarstwo, do którego skłonne byłyby białogłowy. Ostrze prześmiewczego zestawienia dotyczy raczej zwyczaju, ściśle łączącego się z kokieteryjnymi zabiegami wdzięczących się panien. Jego echem jest satyryczny obrazek, nakreślony w cytowanym już XVII-wiecznym Wierszu o fortelach i obyczajach białogłowskich. Do ukazanych tu fortelów mieszczańskiej panienki, dbałej o przynęcanie młodzieńców, należy także ten:

A kędykolwiek stąpi, to zawsze kredeczki

Ukęsuje abo też jęczmienne krupeczki,

Abo też tatarczane często pojaduje,

Abo cytwar lub imbier rada pogryzuje ${ }^{49}$.

${ }^{46}$ Marek Tulliusz Cyceron, $O$ mówcy, trans. et ed. Bartosz Awianowicz (Kęty: Wydawnictwo Marek Derewiecki, 2010), 433 (De oratore II 255: „Sed scitis, esse notissimum ridiculi genus, quum aliud expectamus, aliud dicitur").

${ }^{47}$ Ibidem, 469 (De oratore II 289: „expectationibus enim decipiendis [...] risus moventur”).

${ }^{48}$ Albertus Magnus, De animalibus libri XXVI [...], ed. Hermann Stadler, vol. 2 (Münster in Westfalen: Verlag der Aschendorffschen Verlagsbuchhandlung, 1920), s. 1440: „Alii autem dicunt ardeam dictam ab ardendo quia stercus eius adurit hoc quod contingit: et hoc commune habet cum aliis aquaticis avibus quae de venatione piscium vivunt. Haec autem avis [...] sicut aliae aves aquaticae non multum involuti est intestini: et ideo sicut et mergus emittit cibum indigestum, et ideo semper est vorax avis ista, et ideo etiam est fetidae carnis et non sanae. [...] Stercore autem suo exsiccant omnes arbores in quibus nidificant. Si autem aliquando accipiter praedari nititur ardeam, anum opponit accipitri et stercus proicit putrefactum, quod si forte accipitrem tetigerit, pennas eius putrefacit”.

${ }^{49}$ Polska satyra mieszczańska, op. cit., 155 (w. 125-128). 
A ponieważ wersy te następują po wzmiance o wypytywaniu się o kawalerów „przed kamienicą”, można mniemać, że owo częste „ukęsowanie”, „pojadanie” i „pogryzanie" stanowiło istotny element zalotnego arsenału przechadzających się dzieweczek ${ }^{50}$. Jęczmienne i tatarczane „krupeczki” musiały więc być przygotowane tak, by dało się po nie sięgać idąc. Zapewne upieczone na słodko lub pod postacią słodkich i aromatycznych sucharków? ${ }^{51}$ Żucie "gwoździkow cytwaru" bądź „imbieru” służyło, jak się zdaje, uzyskaniu wonnego oddechu ${ }^{52}$. Niewykluczone wreszcie, że podgryzanie kredy - zgodnie ze świadectwem XVI-wiecznego medyka francuskiego, Jeana Liébaulta, wynikało z przeświadczenia, że spożycie wysuszającego proszku pozwala zachować szczupłą figurę ${ }^{53}$.

Jeśli więc porównanie Rejowe godziło w ten przejaw niewieściej kokieterii, niosło zrazu niespodziewane rozwinięcie stwierdzenia „Białogłowy nasze są podobne czaplam", by po chwili uzmysłowić, że obraz nieustannie jedzącego ptaka nie unieważnia bynajmniej skojarzenia z umizgującą się czaplą „w kobieli”. Zjadliwy przytyk nie ogranicza się wszakże do zestawienia żarłocznego a wciąż wychudzonego zwierzęcia $\mathrm{z}$ białogłowami powabnie pogryzającymi służące urodzie drobne przekąski. Mowa bowiem nie tylko o wciąż żerującej, lecz także wciąż roniącej odchody czapli. Struktura „podobieństwa”, które otwiera się formułą „jako czapla bez przestanku je, a gdziekolwiek leci, to z niej pierzcha”, nakazuje spodziewać się, że po słowach „tak białegłowy ustawicznie jedzą i ustawicznie...” nastąpi skatologiczne domknięcie porównania.

Jednakże i tym razem oczekiwania słuchaczy zostaną zawiedzione. Ich spełnienie wymagałoby przecież spuentowania wypowiedzi uwagą o ustawicznej biegunce $-\mathrm{z}$ pewnością prześmiewczą, ale nijak nie przystającą do rzeczywistości. W miejsce spodziewanej puenty padają przeto słowa: „ustawicznie też chodzą dla chłodu na komorkę". Stanowią one prawdopodobnie drwiącą aluzję do pretekstu, jakiego używały dworne niewiasty, by opuścić towarzystwo. Damy oznajmiały zapewne, że muszą udać się do „komorki”, czyli do pokoju, izby ${ }^{54}$, „dla chłodu” - dla ochłody, odświeżenia, nabrania sił.

W zamknięciu ,podobieństwa” mechanizm rozbudzania śmiechu przez zaskoczenie mógł więc zostać użyty ponownie. Ponownie też domysł słuchacza,

${ }^{50}$ Ibidem (w. 121-125).

${ }^{51}$ Cf. Jarosław Dumanowski, Staropolskie wariacje na temat kaszy, http://www.wilanow-palac.pl/ staropolskie_wariacje_na_temat_kaszy.html (acc. 31.10.2016).

${ }^{52}$ Marcin Siennik, Herbarz, to jest Ziót tutecznych, postronnych $i$ zamorskich opisanie [...] (Kraków: w drukarni Mikołaja Szarfenberga, 1568), 358: „Czosnku albo cebule z ust śmierdzenie. Ruty natychmiast zjeść abo gwoździkow cytwaru, abo miodunki z octem nawierciawszy wypić”; 360: Przeciw cuchnieniu z ust. Wonią z ust naprawia żwanie gwoździkow kramnych [...]”.

${ }^{53}$ Jean Liébault, Trois livres de l'embellissement et ornement du corps humain (Paris: chez Iacques du Puys, 1582), 22; vide Georges Vigarello, Historia urody: Ciało i sztuka upiększania od renesansu do dziś, trans. Maciej Falski (Warszawa: Wydawnictwo Aletheia, 2011), 50.

${ }^{54}$ Stownik polszczyzny XVI wieku, vol.10 (Wrocław: Ossolineum, 1976), 509-510 (s.v. komorka). 
tym razem skatologiczny, nie został wprawdzie potwierdzony, ale nie został również unieważniony. Jakkolwiek bowiem nie padają spodziewane słowa, odpowiadające obrazowi czapli, z której „pierzcha”, to wytworna wymówka rozbrzmiewała pewnie i wówczas, gdy białogłowa oddalała się do „potrzebnej komorki”" ${ }^{55}$.

Przypisane Rejowi porównanie, podporządkowane wymogom trefności, oparte na grze z oczekiwaniami słuchaczy, nie pobłażające niewieścim słabościom, ale też dalekie od wzgardy wobec kobiet, stanowi w dziele Górnickiego nie tylko przykład „foremnie” „przystosowanego” „przyrównania”. Inaczej niż dwa okalające je przykłady zaczerpnięte z Cycerona, współgra ono zarazem z wywodami o „wydwarzaniu”, którego powinien wystrzegać się tak dworzanin, jak i dworna pani. Dowodząc, ,jako przemierzła rzecz jest wydwarzanie”, natomiast „szczyrość a niedbałe jakieś czynienie rzeczy" odznacza się wdziękiem, Kryski piętnuje wysilone i sztuczne zabiegi kobiet, co to „gwałtem chcą być piękne” (96-97, do 99). Zgodnie zaś z przestrogą Derśniaka, „gdy wydwarzanie wynidzie z miary, uśmiać sie mu człowiek musi” (224). I właśnie do śmiechu z „wydwarzania” pobudzało Rejowe zestawienie białogłów z czaplami.

\section{Panie, a wszak u Tarła?, czyli najsubtelniejsza trefność}

W Dworzaninie Castiglione'a krótki wywód o najdoskonalszej odmianie zwięzłych i w porę wypowiedzianych żartów otwiera się stwierdzeniem, że rodzą się one z dwuznaczności. Messer Bernardo podkreśla przy tym, że ich przemyślność może niekiedy wzbudzać nie tyle śmiech, ile podziw. I za przykład dowcipnej i podziwu godnej wypowiedzi podaje słowa, jakimi Annibal Paleotto skwitował propozycję, by do nauczania swych synów zatrudnił wielce uczonego mistrza. Gdy zachwalający nauczyciela rozmówca wspomniał, że oprócz pieniędzy trzeba będzie zapewnić mu komnatę do mieszkania i spania, bo nie ma łóżka, messer Annibal odparł z miejsca: „Jakżeż może być uczony, skoro nie ma łóżka?” A ponieważ włoskie „non aver letto” ma dwa znaczenia, cięta odpowiedź znaczyła jednocześnie: „Jakżeż może być uczony, skoro nie czytał?”56.

Przekład tego fragmentu musiał być przedmiotem głębszego namysłu Górnickiego, albowiem we wprowadzeniu do Pirwszej ksieggi pisarz wyznaje:

A gdy do facecyj przychodzi, tam sie wiele rzeczy zaniechało, wiele odmieniło; bo [...] owo: come può esser egli dotto, se non ha letto? - żadnym sposobem tak w polszczyźnie uść by nie mogło [12].

${ }^{55}$ Stownik polszczyzny XVI wieku, vol. 28 (Warszawa: Instytut Badań Literackich, 2000), 467, kol. prawa (s.v. potrzebny).

${ }^{56}$ B. Castiglione, op. cit., 166 (II 58). 
W Dworzaninie polskim przeto Jan Derśniak poprzestaje na zaznaczeniu, iż „najsubtelniejsza” z rychłych, krótkich i dowcipnych wypowiedzi wynika ze „słowa abo rzeczy dwuwykładnej” (228). Następnie zaś, nie napomykając, że „trefność” tego rodzaju wywołuje czasem raczej podziw niż wesołość, przedstawia opowiastkę o dworzanach wybierających się na ucztę „u pana Mikołaja Tarła”. Być może takie wprowadzenie anegdoty o Rejowym „rzeczeniu” wskazywać miało na jego nieodparcie rozśmieszający charakter ${ }^{57}$.

Z pewnością zaś zastąpienie historii o mistrzu bez łóżka historią o skatologicznej wypowiedzi na królewskim dworze przyniosło więcej niż zmianę tematyki przywołanego przykładu. Oto przecież puenta dykteryjki o Annibalu Paleotto współtworzy i domyka spójną całość. Dwuznaczność jego zjadliwego pytania nie tylko podważa wygłoszoną wcześniej pochwałę mistrza, ale też obnaża bezzasadność powiązanych z nią roszczeń. Ubóstwo nauczyciela nie poświadcza bowiem wiarygodnie jego wielkiej uczoności. Tymczasem puenta facecji Jana Derśniaka odsyła poza to, co zostało w niej opisane:

[...] mając raz dworzanie jeść u pana Mikołaja Tarła, chorążego sędomirskiego, pytał jeden drugiego przed królem stojąc: „Panie, a wszak u Tarła?” - Jaki taki odpowiedział: „U Tarła”; aż do pana Reja przyszło, który, gdy go też spytano: „Panie, a wszak u Tarła?” - on zaraz, by z bicza, ze dwu jedno uczynił słowo i rzekł: „Wie ją djabeł, jać-em jej tam w ogon nie patrzał” [229].

Błyskawiczne uczynienie $\mathrm{z}$ dwu słów jednego sprawia, że czcigodne grono królewskich dworzan przeobraża się $\mathrm{w}$ gremium roztrząsające $\mathrm{z}$ troską kwestię: utarła zadek, czy nie utarła? O kim jednak mowa, nijak nie wynika z przytoczonej anegdoty. Jeśli zaś „rzeczenie” Reja kieruje uwagę ku - nie wymienionej w opowieści - postaci i jeśli miałoby wzbudzać śmiech, to warto rozważyć, czy nie mogło ono stanowić aluzji do jakiejś skatologicznej dykteryjki, dobrze znanej dworzanom wybierającym się na ucztę do „chorążego sędomirskiego”. Byłoby to zgodne z przedstawioną przez Górnickiego - za Castiglionem i Cyceronem - drogą rozweselania słuchaczy przy użyciu dwuznacznej wypowiedzi. Bo chociaż „takie rzeczenie barziej dziwne jest, niż śmieszne”, to wywoła ono uciechę, gdy „k niemu druga trefność przystąpi”, czyli wtedy, kiedy powiązane zostanie $\mathrm{z}$ innym żartem $(230)^{58}$.

${ }^{57}$ Przypuszczenie to potwierdzają słowa Derśniaka po przytoczeniu anegdoty o uczcie u Tarła: „Ale nie zawdy takowe rzeczenie trefne być może, więcej sie mu pospolicie ludzie dziwują jako temu, które z bystrego rozumu pochodzi, niż aby mu sie barzo śmiać miano. A czasem ani kęs jeden ma śmiechu w sobie, owszem, statek a powagę" (229).

${ }^{58}$ Cf. B. Castiglione, op. cit., 166 (II 58): „Ma perché questi motti ambigui hanno molto dell'acuto, per pigliar l'omo le parole in significato diverso da quello che le pigliano tutti gli altri, pare, come ho detto, che piú presto movano maraviglia che riso, eccetto quando sono congiunti con altra manera di detti”; Cyceron, op. cit., 430-432: ,,ambiguum per se ipsum probatur id quidem, ut ante dixi, vel maxime; ingeniosi enim videtur vim verbi in aliud, atque ceteri accipiant, posse ducere; sed admirationem magis quam risum movet, nisi si quando incidit in aliud quoque genus ridiculi” (De oratore II 254). 
W 1568 roku w Bazylei ukazał się zbiór Johannesa Hulsbuscha Sylva sermonum iucundissimorum, in qua nouae historiae et exempla uaria, facetiis undique referta, continentur [...]. W liście dedykacyjnym autor nadmienia, że pomieścił tu łacińskie przekłady wybranych przez siebie niemieckich facecji ${ }^{59}$. Wydobył je między innymi z kolekcji Montanusa, Wickrama, Freya, Schumanna, Hertzoga i Pauliego ${ }^{60}$. Z Sylva sermonum Mikołaj Rej zdążył jeszcze zaczerpnąć kilkanaście powiastek do opublikowanej już po jego śmierci drugiej edycji Przypowieści przypadłych, czyli Figlików ${ }^{61}$. Co jednak istotniejsze dla zrozumienia przypisanej mu w Dworzaninie polskim „trefności”, pośród dykteryjek zgromadzonych i przetłumaczonych przez Hulsbuscha znajduje się facecja o służącej, która „przez rok nie podcierała zadka”:

\section{Ancilla non tersit podicem uno anno}

In oppidulo quodam exercebat textrinam laneam diues, cui magna erat familia. Quum is subinde emeret multum lanarum, reperit aliquoties pugillos lanarum in latrina, qua familia utebatur (sit uenia dicto) tergendo podici, quod aegre ferebat. Quaerit ergo ab uxore, num illa locasset lanam ibidem, quod negauit illa. Similiter sciscitatur a seruis, qui et ipsi negauerunt. „Oportet autem quenquam hoc designasse" ait, simulque iubet accersiri ancillam. Illa licet caetera obscoena, excusat se quam bene potest, dicens: „Vere non sum huius rei conscia, here mi, nam annus est quam non tersi posteriora mea. Verum si meis uerbis non uis adhibere fidem, inspicito podicem meum ipsemet: si contrarium repereris, habear ergo rea". Commotus herus ad hoc inquit: „Daemon inspiciat tibi podicem, ego tibi potius credidero, uideo enim te satis obscoenam esse". Cogebatur herus hoc responso sibi ipsi satisfacere ${ }^{62}$.

Dykteryjka o niefortunnym śledztwie bogatego właściciela warsztatu tkackiego wiąże się ze znanym w średniowieczu obyczajem używania wełny do, „za przeproszeniem”, jak ujął to Hulsbusch, „podcierania zadków”63. Jest też zapewne szczególnym odzwierciedleniem XVI-wiecznej drożyzny tego surowca ${ }^{64}$. Obdarzony liczną rodziną sukiennik stropił się, gdy kilkakroć natrafił w latrynie na garście wełny. Obawiając się zapewne szybkiego uszczuplenia jej cennych zasobów, postanowił dociec, kto wynosi ją do wychodka. Gdy zaś ani żona,

${ }^{59}$ Ioannes Hulsbusch, Sylva sermonum iucundissimorum, in qua nouae historiae et exempla uaria, facetiis undique referta, continentur [...] (Basileae: apud Samuelem Apiarium, 1568), k. A3r: „Amant alterna Camoenae, nec uult arcus semper tendi. Hoc consilio ductus et ego, locaui aliquot horas in uertendo ex lingua Germanica facetias aliquot iucundas, et quae remissiorem spiritum reficere et excitare queant, deligens ex multis, quae mihi uisae sunt urbaniores, et minus uel fellis, nasi uel scommatis habere".

${ }^{60}$ Vide Johannes Bolte, „Vorwort”, in Georg Wickram, Werke, vol. 3, ed. Johannes Bolte (Tübingen: Litterarische Verein in Stuttgart, 1903), XIII.

${ }^{61}$ Vide I. Chrzanowski, „Facecje”, op. cit., 360-364.

${ }^{62}$ I. Hulsbusch, op. cit., 209-210.

${ }^{63}$ Vide Ian Mortimer, The Time Traveler's Guide to Medieval England: A Handbook for Visitors to the Fourteenth Century (New York: Touchstone, 2008), 162.

${ }^{64}$ Vide Georg Wiebe, Zur Geschichte der Preisrevolution des XVI. und XVII. Jahrhunderts (Leipzig: Verlag von Duncker \& Humblot, 1895), 156, 328, 345, 349, 356, 371, 372, 385. 
ani słudzy nie przyznali się do występku, nakazał przyprowadzić ostatnią podejrzaną - niechlujną służącą. Ta zaś wybroniła się zręcznie, zapewniając, że już od roku nie podciera zadka, i na dowód swej niewinności zażądała, by pan - jeśli nie wierzy jej słowom - przekonał się o tym naocznie. Wobec takiej odpowiedzi rzemieślnik okazał się bezradny. Oburzony, wybuchną: „A niechże diabeł zagląda ci w zadek! Ja zaś raczej ci uwierzę, bo widzę, że jesteś dostatecznie plugawa”.

Kiedy przeto na pytanie: „Panie, a wszak u Tarła?”, Rej odpowiada z nagła: „Wie ją djabeł, jać-em jej tam w ogon nie patrzał”, jego „rzeczenie” odsyła wprost do facecji o przemyślnej służce sukiennika. A skoro, jak uczył Cyceron, zastosowanie dwuznaczności „wymaga talentu, by znaczenie słowa [...] skierować na coś innego, co by też inni zrozumieli”, to i rozśmieszające powiązanie dwuznaczności z ,jakimś innym rodzajem żartu” ${ }^{55}$ mogło być skuteczne o tyle, o ile Rejowa aluzja była zrozumiała dla pozostałych dworzan. Przywołana zatem w wykładzie Derśniaka anegdota o uczcie u Tarła stanowi świadectwo znajomości na dworze królewskim niemieckiej dykteryjki, zanim została ona przełożona na łacinę i ogłoszona w zbiorze Hulsbuscha. Ponieważ jednak Górnicki nie objaśnił, dlaczego przypisana Rejowi „trefność” wzbudziła wesołość, a nie tylko podziw, dopiero filologiczne dochodzenie pozwala rozświetlić przyczyny przedstawienia skatologicznego „rzeczenia” jako przykładu najsubtelniejszej odmiany dwornego trefnowania.

Odsłonięcie głębszego sensu dwu przypisanych Rejowi „trefności” wymaga odejścia od traktowania ich jako wiernego przytoczenia słów autora Figlików. Być może wypowiedział je rzeczywiście, i to nawet dokładnie w takim brzmieniu, w jakim przekazane zostały przez Górnickiego. Wszelako znacznie istotniejsza od ich prawdziwości jest zgodność z przedstawioną we wstępie do Pirwszej księgi zasadą prawdopodobieństwa. Skłania ona do rozpatrywania związanych z Rejem zdarzeń i „rzeczeń” jako czy to wybranych, czy przekształconych, czy wręcz wymyślonych przez Górnickiego po to, by spełniały założone przez niego cele. Odkrycie zaś ich roli w wywodzie o dwornym trefnowaniu wymaga przeprowadzenia szczegółowej analizy z wykorzystaniem kontekstu tak Dworzanina polskiego i jego źródeł, jak i utworów pokrewnych tematycznie lub gatunkowo obu wypowiedziom. Oparta na takich założeniach interpretacja oświetla złożoność, sens i funkcję skatologicznych żartów, a zarazem pozwala zrozumieć przyczyny ich wysokiej oceny przedstawionej przez Górnickiego. Przekonuje wreszcie, że Dworzanin polski kryje jeszcze wiele tajemnic, które domagają się szczegółowych, filologicznych dociekań.

${ }^{65}$ Cyceron, op. cit., 433 (De oratore II 254). Cf. ibidem, 429 (De oratore II 250), 431 (De oratore II 253). 


\section{REJ AS PERCEIVED BY GÓRNICKI. PHILOLOGICAL INVESTIGATION ON SCATOLOGICAL JESTING}

\section{Su m m a ry}

The second book of The Polish Courtier, Łukasz Górnicki's paraphrase of Castiglione's The Book of The Courtier, contains a study of courtly jesting. This is where, among other jests, two scatological jokes attributed to Mikołaj Rej appear. Most scholars considered them as evidence of a coarse sense of humour, incompatible with courtly pleasantry. And yet Górnicki treated Rej's witticisms as superb examples of sophisticated jesting. The article presents an analysis of these jokes in the context of Górnicki's discourse on courtly wit, Castiglione's The Book of The Courtier, Cicero's De oratore, Renaissance jests and old Polish satirical poetry. The analysis reveals complexity, unobvious meanings and the function of scatological witticisms attributed to Rej and allows to understand reasons for the high regard in which Górnicki held them. 